\title{
APPLICATION OF FMEA IN THE QUALITY ESTIMATION OF METAL MATRIX COMPOSITE CASTINGS PRODUCED BY SQUEEZE INFILTRATION
}

\begin{abstract}
Metal matrix composites (MMCs) are still scarcely described due to various combinations of used materials and a wide array of technologies. Applying the Failure Mode and Effect Analysis (FMEA) method to describe the quality of metal composite castings may contribute to eliminating specific (characteristic only to these materials) defects. This part of the analysis determines the criticality numbers, meaning the frequency of a given failure, detectability level and significance of a given failure to the group of specific composite casting failures. It contributes to establishing the priority number $(\mathrm{P})$, which is a measure used to assess risk, a notion essential in discussing quality in a composite casting.

Keywords: quality, casting, metal matrix composites, MMC, Failure Modes and Effects Analysis, FMEA, material defects,
\end{abstract} failures

\section{Introduction}

Quality of castings is affected, among other things, by factors related to order-specific requirements [1,2], along with strictly technological issues, such as designing a casting technology, casting materials, metal melting, filling the mould with metal, solidification, crystallisation, cooling and removing the casting from its mould. Failures in castings, also in MMCs made by infiltration of porous preforms, are created throughout the entire production process [3]. Defect of a similar character may occur on various stages, result from different factors, or even stem from dissimilar mechanisms. It is possible to quote the example of cracks in reinforcement elements, which may be created during production, solidification, cooling or even removing from the mould.

The course of producing castings from conventional materials has been well researched [4,5]. In cases of MMCs made by infiltration of porous preforms, the presence of permanent reinforcement, usually taking up from several to nearly $30 \%$ of the casting volume, significantly modifies the course of the discussed process. To examine the quality of MMCs made by infiltration of porous performs, FMEA analysis should be conducted. It would not be possible to identify and describe several basic failures specific for castings made of such composites without assuming such an approach.

\section{Methodology}

Composite materials analysed in the paper were produced by pressure infiltration of porous short or long carbon, boron, steel, aluminosilicate fibres perform under 15-30 MPa extend pressure using liquid aluminium and Wood's alloys (technology introduced in [1-3].)

The quality of the product, namely a metal ceramic casting, after the completion of the technological process was analysed in accordance with quality standards [6,7]. The factors determining the manner of creating the product (composite castings) are the demands (orders) of the recipients, specifying needs concerning the casting. Said agents influence the course of further actions. Gaining information on strong and weak points of the technological process as well as the product itself is crucial as it makes it possible to introduce conceptual changes before commencing structural work. One of many applications of a Failure Mode and Effect Analysis [8,9] is the instance of introducing new materials as well as new or modified technologies. The goal of FMEA is to consistently eliminate failures of production by identifying the reasons for their presence and applying measures accurately preventing them. In the case of FMEA, after specifying the object of research, the analysis concerning reasons of failure and their criticism for the following stages must be conducted:

- determining the goal of the analysis - the objective in the present analysis is to produce a good quality composite casting,

- gathering data and screening failures.

\footnotetext{
* MARITIME UNIVERSITY OF SZCZECIN, FACULTY OF MARINE ENGINEERING, DEPARTMENT OF SHIPBUILDING MATERIALS ENGINEERING, 2-4 WILLOWA STR., 71-650 SZCZECIN, POLAND ** MARITIME UNIVERSITY OF SZCZECIN, FACULTY OF MARINE ENGINEERING, MARINE PROPULSION PLANTS DEPARTMENT, 1-2 WALY CHROBREGO STR., 70-500 SZCZECIN, POLAND *** BP MARITIME SERVICES (SINGAPORE) PTE. LIMITED, 1 HARBOUR FRONT AVENUE, \#02-01KEPPEL BAY TOWER, SINGAPORE 098632 
This paper is based on a classification of defects in the structure of infiltrated metal composite castings [11-13], creating an entire group in the classification of casing defects (Fig. 1). It bears the name of structure defects, just as suggested in $[1,13]$. Other groups (shape defects and raw surface defects) included in the classification correspond with groups differentiated in the casting failure classification for conventional materials. This group (structure defects) consists of 5 subgroups encompassing both structure defects in castings made of conventional materials, corresponding to those for infiltrated composite castings, and failures specific for such castings. Only those defects will be submitted to the FMEA method analysis.

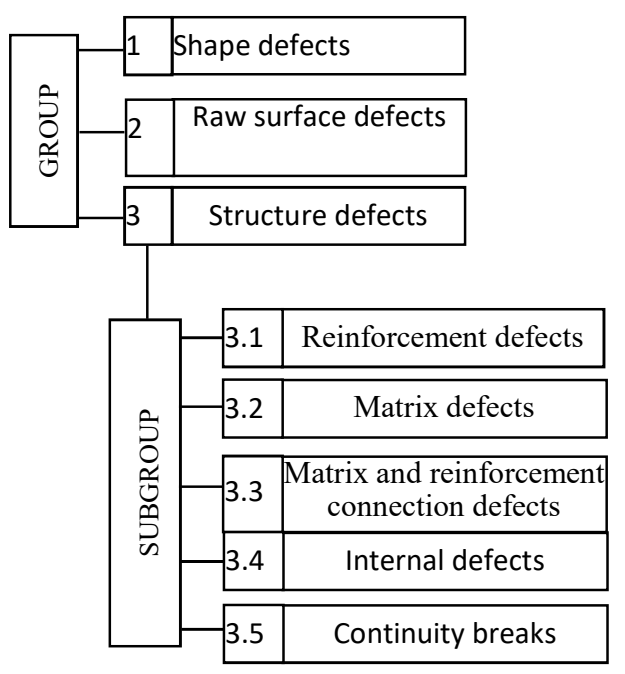

Fig. 1. Structure of classification of defects in metal matrix infiltrated composite castings (based on authors' work)

Determining reasons and consequences of failures. Establishing the causes of failures in the analysed product was discussed in the works of [1,8,14-15], using e.g. the Pareto and Ishikawa analysis. The next step regarded a quantitative analysis, namely determining the possibility of each failure. This undertaking aims at assessing risk factors. Each defect is given a whole number between 1 and 10 based on three criteria: frequency of occurrence $R$ (Table 1), level of detectability $W$, describing the likelihood of a given failure being overlooked by the producer and presenting itself to the customer (Table 2), and severity of the defect $Z$ from the standpoint of product recipient (Table 3 ).

TABLE 1

Frequency of failure for composite castings [9]

\begin{tabular}{|c|l|c|}
\hline Frequency & \multicolumn{1}{|c|}{ Characteristics of the process/product } & $\boldsymbol{R}$ \\
\hline Unlikely & $\begin{array}{l}\text { A failure is highly unlikely. The technological } \\
\text { process is perfected and fully controlled. }\end{array}$ & 1 \\
\hline Remote & $\begin{array}{l}\text { Relatively low level of failures. Controlled } \\
\text { process. }\end{array}$ & $2-3$ \\
\hline Occasional & Failures happen from time to time. & $4-6$ \\
\hline $\begin{array}{c}\text { Reasonably } \\
\text { possible }\end{array}$ & Failures occur often, in a regular manner. & $7-8$ \\
\hline Frequent & It is almost impossible to avoid failures. & $9-10$ \\
\hline
\end{tabular}

Failure detection levels for composite castings [9]

\begin{tabular}{|c|l|c|}
\hline \hline Detectability & \multicolumn{1}{|c|}{$\begin{array}{c}\text { Characteristics } \\
\text { of the process/product }\end{array}$} & $W$ \\
\hline Certain & $\begin{array}{l}\text { It is highly unlikely that the failure will not be } \\
\text { detected. Verification using proper material } \\
\text { examination after the technological process. }\end{array}$ & $1-2$ \\
\hline High & $\begin{array}{l}\text { Low possibility of not detecting the fault } \\
\text { before process completion. The failure is } \\
\text { evident, a few may remain undetected. } \\
\text { Verification using proper material examination } \\
\text { after the technological process. }\end{array}$ & $3-4$ \\
\hline Moderate & $\begin{array}{l}\text { Moderate likelihood of not detecting product } \\
\text { fault before process completion. Verification } \\
\text { using proper material examination after the } \\
\text { technological process. }\end{array}$ & $5-6$ \\
\hline Low & $\begin{array}{l}\text { High possibility of not detecting the failure, } \\
\text { even if proper material examination applies. }\end{array}$ & $7-8$ \\
\hline Very low & $\begin{array}{l}\text { Extremely high likelihood of the fault } \\
\text { remaining undetected, even if proper material } \\
\text { examination applies. }\end{array}$ & $9-10$ \\
\hline
\end{tabular}

TABLE 3

Consequences (severity) of failures in composite castings (ramifications for customers) [9]

\begin{tabular}{|c|c|c|}
\hline Consequences & $\begin{array}{c}\text { Characteristics } \\
\text { of the process/product }\end{array}$ & $Z$ \\
\hline Not relevant & $\begin{array}{l}\text { Minimal effect, failure will not affect } \\
\text { application. }\end{array}$ & 1 \\
\hline Minor & $\begin{array}{l}\text { Minimal effect causing slight inconvenience. } \\
\text { Moderate deterioration of product properties } \\
\text { may be noticed. }\end{array}$ & $2-3$ \\
\hline Moderate & $\begin{array}{l}\text { Failure leads to slight dissatisfaction and } \\
\text { inconvenience. Product does not satisfy needs } \\
\text { or is a source of annoyance. Users notice } \\
\text { flaws of the product. However, it may be } \\
\text { authorised. }\end{array}$ & $4-6$ \\
\hline Critical & $\begin{array}{l}\text { Customer dissatisfaction is stronger. Product } \\
\text { may not be used. Failure leads to producing } \\
\text { a casting not fitting the requirements. }\end{array}$ & $7-8$ \\
\hline Catastrophic & $\begin{array}{l}\text { The ramification of the failure is grave, the } \\
\text { casting is disqualified, threatens the safety of } \\
\text { users or violates the law. }\end{array}$ & $9-10$ \\
\hline
\end{tabular}

On the basis of estimated criticality numbers, a Risk Priority Number $P$ has been calculated per the formula [8]:

$$
P=R \cdot Z \cdot W
$$

The values assigned to $P$ fall between 1 and 1000 [8]. The higher the value of the priority number $(P)$, the greater the risk related to a given failure. In most cases, a specific critical level is assumed, namely the value of the priority number $P$, e.g. $P>100$; all failures with a higher value will be analysed. As a rule, if the defect critical level is significantly higher than 1 , it is recommended to go to the next level of action, namely apply preventive measures such as changing or rationalising the technical process. 


\section{FMEA analysis}

By virtue of structural specificity of composites, continuity breaks, internal defects as well as failures characteristic to infiltrated composites could be included in one subdivided group. However, preparing this classification would require a detailed analysis of the production process applied to metal composite castings with infiltrated reinforcements, which would be oriented towards determining the possibility of failures on individual stages of said process. The suggested group bears the name: structural defects. This is the reason why the paper discusses only this group, namely the structural defects of composite metal with infiltrated reinforcements, combined into one group of cast- ing defects according to [1]. Other groups of failures (shape and raw surface) included in the classification correspond with those enlisted in the classification of defects for conventional material castings. The structural defects group is made of 5 subgroups dealing with both structural failures of castings made of conventional materials, applicable also to structural failures of infiltrated materials castings, and defects specific to composite castings. Five subgroups, namely reinforcement failures, matrix defects, matrix and reinforcement connection defects, internal defects and continuity breaks, classify failures discussed in Tables 4-8. The priority number and 3 critical failures were determined on the basis of calculated criticality numbers.

FMEA for the reinforcement defects subgroup (based on authors' work)

\begin{tabular}{|c|c|c|c|}
\hline Defect & $\begin{array}{l}\text { Defect significance for customer } \\
\text { (consequences, results) }(Z)\end{array}$ & Frequency $(R)$ & $\begin{array}{l}\text { Detectability }(W) \text { for conventional material castings }[1,13] \\
\text { and composite castings using proper research methods }\end{array}$ \\
\hline $\begin{array}{l}\text { Inhomogeneity } \\
\text { of shape and di- } \\
\text { mensions of the } \\
\text { reinforcement } \\
\text { elements }\end{array}$ & $\begin{array}{l}\text { Minimal effect causing slight inco- } \\
\text { nvenience. Moderate deterioration of } \\
\text { product properties may be noticed. } \\
\mathbf{Z = 2} \\
\text { Defect description: Varied length, } \\
\text { width, shape and shape of fibres }\end{array}$ & $\begin{array}{l}\text { Failures occur } \\
\text { often, in a re- } \\
\text { gular manner. } \\
\boldsymbol{R}=7\end{array}$ & $\begin{array}{l}\text { Low possibility of not detecting the fault before process comple- } \\
\text { tion. The failure is evident, a few may remain undetected. Verifi- } \\
\text { cation using proper material examination after the technological } \\
\text { process. } \\
\text { - Microscopic examination: } \\
\text { - light, } \\
\text { - electron, scanning } \\
\text { - Microtomography. } \\
\text { - Computer image analysis. } \\
W=3\end{array}$ \\
\hline
\end{tabular}

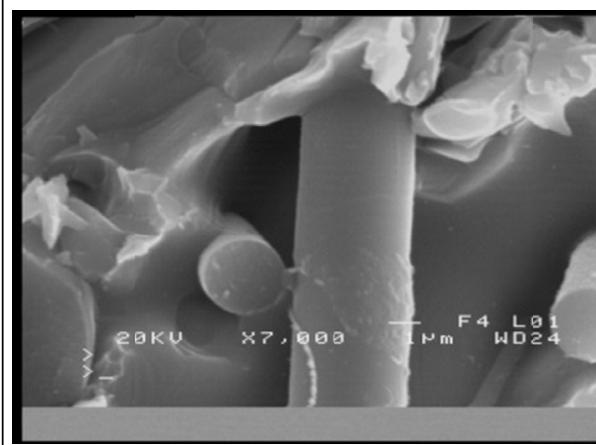

Material:AlSi11/ aluminosilicate, SEM Risk Priority Number $\boldsymbol{P}=\mathbf{4 2}$

\begin{tabular}{|c|c|c|c|}
\hline $\begin{array}{l}\text { Inhomogeneity } \\
\text { of distribution of } \\
\text { the reinforcement } \\
\text { elements }\end{array}$ & $\begin{array}{l}\text { Minimal effect causing slight inco- } \\
\text { nvenience. Moderate deterioration of } \\
\text { product properties may be noticed. } \\
\mathbf{Z = 2} \\
\text { Defect description: } \\
\text { Inhomogeneous density of fibres in } \\
\text { various areas of the reinforcement }\end{array}$ & $\begin{array}{l}\text { Failures happen } \\
\text { from time to } \\
\text { time. } \\
\boldsymbol{R}=\mathbf{4}\end{array}$ & $\begin{array}{l}\text { Low possibility of not detecting the fault before process comple- } \\
\text { tion. The failure is evident, a few may remain undetected. Verifi- } \\
\text { cation using proper material examination after the technological } \\
\text { process. } \\
\text { - Microscopic examination: } \\
\text { - light, } \\
\text { - electron, scanning. } \\
\text { - Microtomography. } \\
\text { - Computer image analysis. } \\
W=4\end{array}$ \\
\hline
\end{tabular}

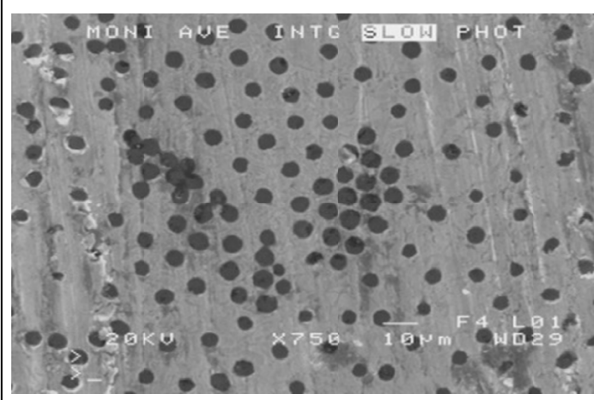


TABLE 4. Continued

\begin{tabular}{|c|c|c|c|}
\hline $\begin{array}{l}\text { Foreign matter in } \\
\text { the reinforcement }\end{array}$ & $\begin{array}{l}\text { Minimal effect causing slight inco- } \\
\text { nvenience. Moderate deterioration of } \\
\text { product properties may be noticed. } \\
\boldsymbol{Z = 3} \\
\text { Defect description: } \\
\text { Contamination in the process of re- } \\
\text { inforcing. }\end{array}$ & $\begin{array}{l}\text { Relatively low } \\
\text { level of failu- } \\
\text { res. Controlled } \\
\text { process. } \\
\boldsymbol{R}=\mathbf{2}\end{array}$ & $\begin{array}{l}\text { Moderate likelihood of not detecting product fault before process } \\
\text { completion. Verification using proper material examination after } \\
\text { the technological process. } \\
\text { - Microscopic examination: } \\
\text { - light, } \\
\text { - electron, scanning. } \\
\text { - X-ray microanalysis. } \\
W=\mathbf{5}\end{array}$ \\
\hline
\end{tabular}

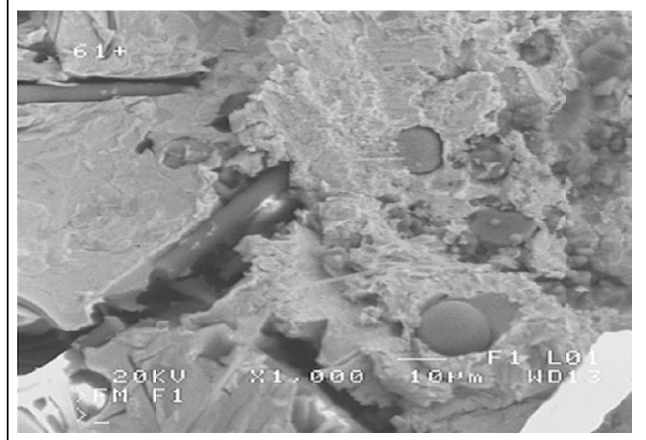

Material: alloy Wood / aluminosilicate, SEM $\quad$ Risk Priority Number $\boldsymbol{P}=\mathbf{3 0}$

\begin{tabular}{|l|l|l|l|}
\hline $\begin{array}{l}\text { Deformation of } \\
\text { the reinforcing } \\
\text { structure }\end{array}$ & $\begin{array}{l}\text { The ramification of the failure is gra- } \\
\text { ve, the casting is disqualified, thre- } \\
\text { atens the safety of users or violates } \\
\text { the law. } \\
\mathbf{Z = 9}\end{array}$ & $\begin{array}{l}\text { Failures happen } \\
\text { from time to } \\
\text { time. }\end{array}$ & $\begin{array}{l}\text { Low possibility of not detecting the fault before process com- } \\
\text { pletion. Verification using proper material examination after the } \\
\text { technological process. } \\
\begin{array}{l}\text { Microscopic examination. } \\
\mathbf{W}=\mathbf{3}\end{array}\end{array}$ \\
$\begin{array}{l}\text { Defect description: } \\
\text { Deformed shape of the reinforce- } \\
\text { ment structure }\end{array}$ & & \\
\hline
\end{tabular}

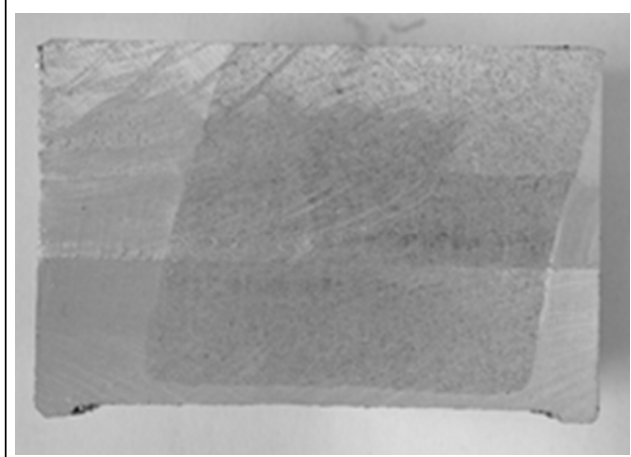

Material: AlSi11 / aluminosilicate, macroscopic $\quad$ Risk Priority Number $P=108$

\begin{tabular}{|l|l|l|l|}
\hline $\begin{array}{l}\text { Improper locali- } \\
\text { zation of the rein- } \\
\text { forcing structure }\end{array}$ & $\begin{array}{l}\text { The ramification of the failure is gra- } \\
\text { ve, the casting is disqualified, thre- } \\
\text { atens the safety of users or violates } \\
\text { the law. } \\
\mathbf{Z = 9}\end{array}$ & $\begin{array}{l}\text { Relatively low } \\
\text { level of failu- } \\
\text { res. Controlled } \\
\text { process. }\end{array}$ & $\begin{array}{l}\text { It is highly unlikely that the failure will not be detected. Verifi- } \\
\text { cation using proper material examination after the technological } \\
\text { process. } \\
\text { - Microscopic examination. } \\
\text { - Radiological defectoscopy. } \\
\text { Ultrasound defectoscopy. } \\
\mathbf{W = 1}\end{array}$ \\
$\begin{array}{l}\text { Defect description: } \\
\text { Relocated reinforcing structure wi- } \\
\text { thin the casting }\end{array}$ & $\mathbf{R = 2}$ & \\
\hline
\end{tabular}

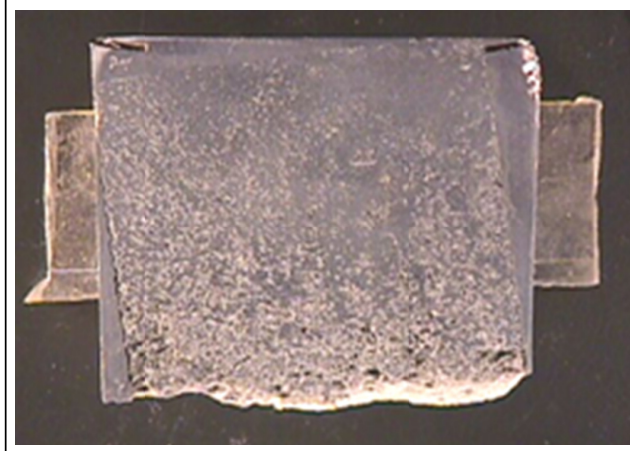


FMEA for the matrix defects subgroup (based on authors'work)

\begin{tabular}{|c|c|c|c|}
\hline Defect & $\begin{array}{l}\text { Defect significance for customer } \\
\text { (consequences, results) }(\mathrm{Z})\end{array}$ & Frequency $(R)$ & $\begin{array}{l}\text { Detectability }(W) \text { for conventional material castings [1,13] } \\
\text { and composite castings using proper research methods }\end{array}$ \\
\hline $\begin{array}{l}\text { Improper matrix } \\
\text { structure }\end{array}$ & $\begin{array}{l}\text { Failure leads to slight dissatisfaction } \\
\text { and inconvenience. Product does } \\
\text { not satisfy needs or is a source of } \\
\text { annoyance. Users notice flaws of } \\
\text { the product. However, it may be } \\
\text { authorised. } \\
\mathbf{Z = 4} \\
\text { Defect description: } \\
\text { Alien phases, undesired dendritic } \\
\text { structure, phases with a fluctuating } \\
\text { chemical composition, coarseness }\end{array}$ & $\begin{array}{l}\text { Relatively } \\
\text { low level } \\
\text { of failures. } \\
\text { Controlled } \\
\text { process. } \\
\boldsymbol{R}=\mathbf{2}\end{array}$ & $\begin{array}{l}\text { It is highly unlikely that the failure will not be detected. } \\
\text { Verification using proper material examination after the } \\
\text { technological process. } \\
\text { - Microscopic examination: } \\
\text { - light, } \\
\text { - electron, scanning. } \\
\text { - Computer image analysis } \\
\text { - X-ray microanalysis } \\
W=1\end{array}$ \\
\hline & 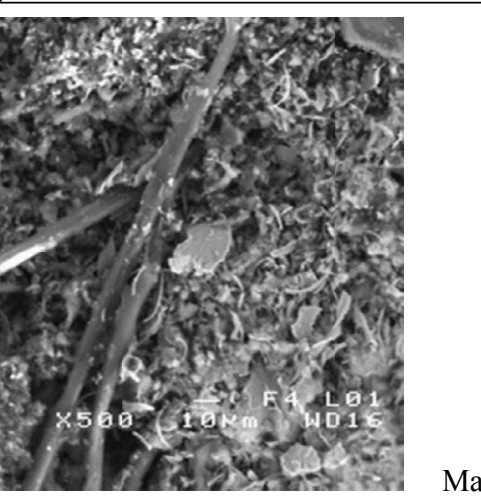 & terial:AlSi11/alu & minosilicate, SEM Risk Priority Number $\boldsymbol{P}=\mathbf{8}$ \\
\hline
\end{tabular}

FMEA for the matrix and reinforcement connection defects subgroup (based on authors' work)

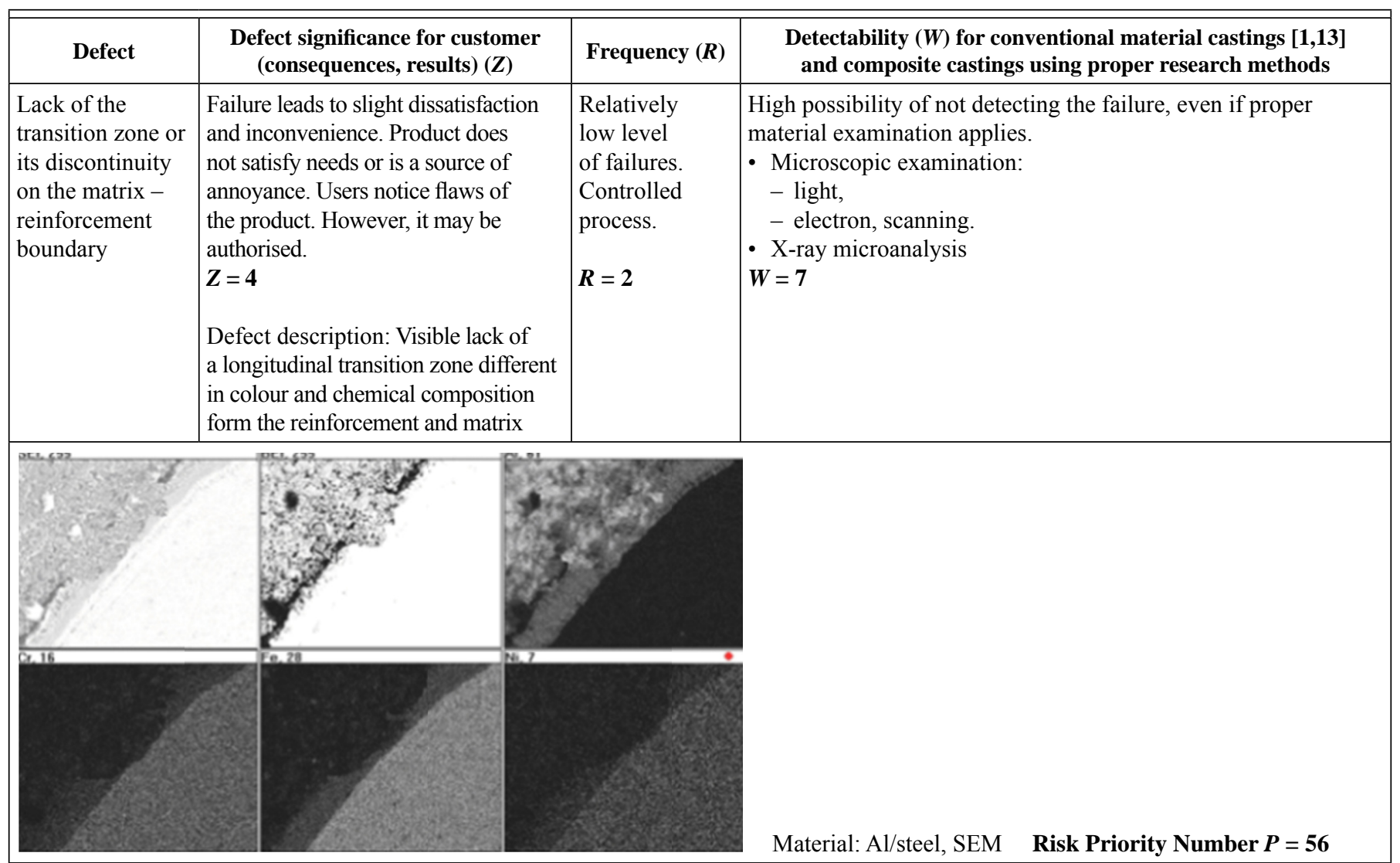


TABLE 6. Continued

\begin{tabular}{|c|c|c|c|}
\hline $\begin{array}{l}\text { Brittle phases } \\
\text { on the matrix - } \\
\text { reinforcement } \\
\text { boundary }\end{array}$ & $\begin{array}{l}\text { Failure leads to slight dissatisfaction } \\
\text { and inconvenience. Product does } \\
\text { not satisfy needs or is a source of } \\
\text { annoyance. Users notice flaws of } \\
\text { the product. However, it may be } \\
\text { authorised. } \\
\mathbf{Z = 4} \\
\text { Defect description: } \\
\text { Continuous or discontinuous brittle } \\
\text { phases on the matrix-reinforcement } \\
\text { boundary }\end{array}$ & $\begin{array}{l}\text { Relatively } \\
\text { low level } \\
\text { of failures. } \\
\text { Controlled } \\
\text { process. } \\
\boldsymbol{R}=\mathbf{2}\end{array}$ & $\begin{array}{l}\text { High possibility of not detecting the failure, even if proper } \\
\text { material examination applies. } \\
\text { - Microscopic examination: } \\
\text { - light, } \\
\text { - electron, scanning. } \\
\text { - X-ray microanalysis } \\
W=7\end{array}$ \\
\hline & 50 & 1: Al/steel, SEM & Risk Priority Number $P=56$ \\
\hline
\end{tabular}

FMEA for the internal defects subgroup (based on authors' work)

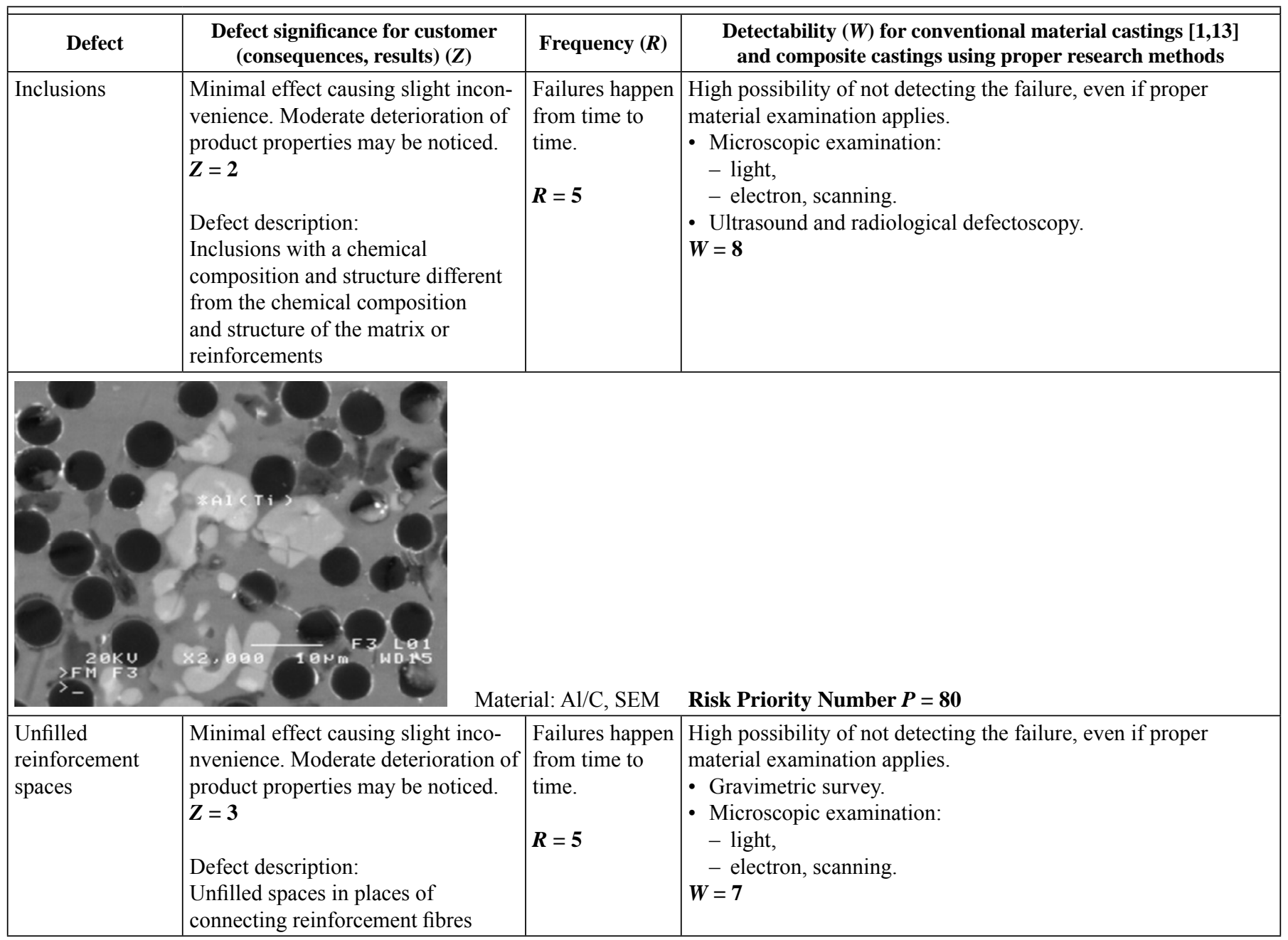


TABLE 7. Continued

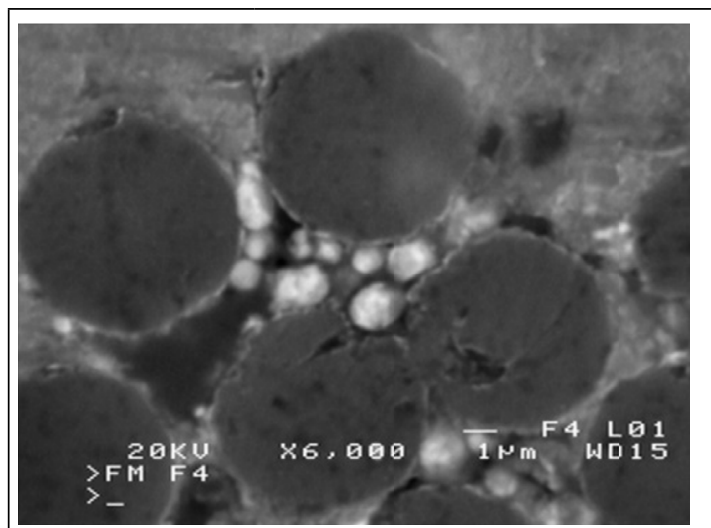

\section{\begin{tabular}{l|l}
\hline Occluded gas & Minimal effect causing slight
\end{tabular}} bubbles inconvenience. Moderate
deterioration of product properties may be noticed.

$Z=2$

Defect description:

Pores in a spherical shape, found in the entire casting, with greater size in its isolated parts

\section{Material: Al/C, SEM Risk Priority Number $P=105$}

\begin{tabular}{|l|l}
$\begin{array}{l}\text { Failures happen } \\
\text { from time to } \\
\text { time. }\end{array}$ & $\begin{array}{l}\text { Extremely high likelihood of the fault remaining undetected, } \\
\text { even if proper material examination applies. } \\
\text { - Macroscopic examination. } \\
\text { - Gravimetric survey. } \\
\text { - Microscopic examination: } \\
\end{array}$ \\
& - light, \\
& - - electron, scanning. \\
& - Computer image analysis. \\
& \\
& \\
& $W=\mathbf{1 0}$
\end{tabular}

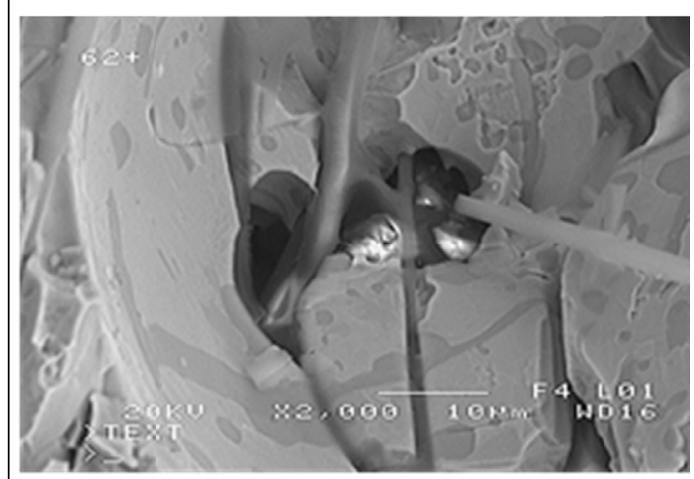

Material: AlSi11/ aluminosilicate, SEM Risk Priority Number $\boldsymbol{P}=\mathbf{8 0}$

\begin{tabular}{|c|c|c|c|}
\hline $\begin{array}{l}\text { Separated gas } \\
\text { bubbles }\end{array}$ & $\begin{array}{l}\text { Failure leads to slight dissatisfaction } \\
\text { and inconvenience. Product does } \\
\text { not satisfy needs or is a source of } \\
\text { annoyance. Users notice flaws of } \\
\text { the product. However, it may be } \\
\text { authorised. } \\
Z=4 \\
\text { Defect description: } \\
\text { Gas pores in a regular spherical } \\
\text { shape }\end{array}$ & $\begin{array}{l}\text { Failures happen } \\
\text { from time to } \\
\text { time. } \\
\boldsymbol{R}=\mathbf{5}\end{array}$ & $\begin{array}{l}\text { Low possibility of not detecting the fault before process } \\
\text { completion. Verification using proper material examination after } \\
\text { the technological process. } \\
\text { - Macroscopic examination. } \\
\text { - Gravimetric survey. } \\
\text { - Microscopic examination: } \\
\text { - light, } \\
\text { - electron, scanning. } \\
\text { - Microtomography. } \\
\text { - Computer image analysis. } \\
\text { - Ultrasound and radiological defectoscopy. } \\
W=\mathbf{4}\end{array}$ \\
\hline
\end{tabular}

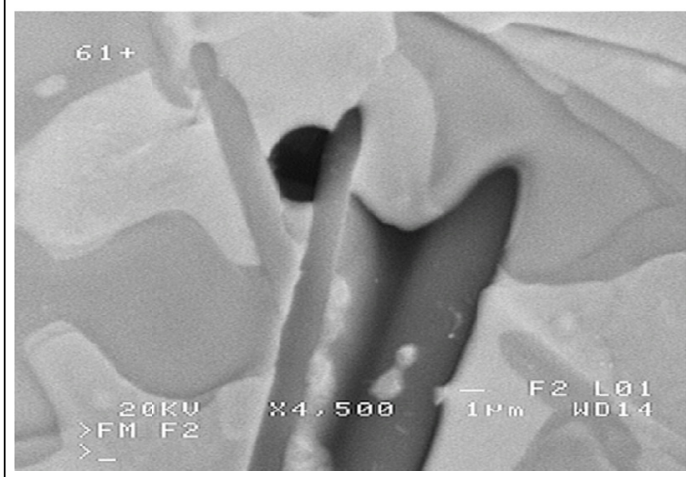


TABLE 7. Continued

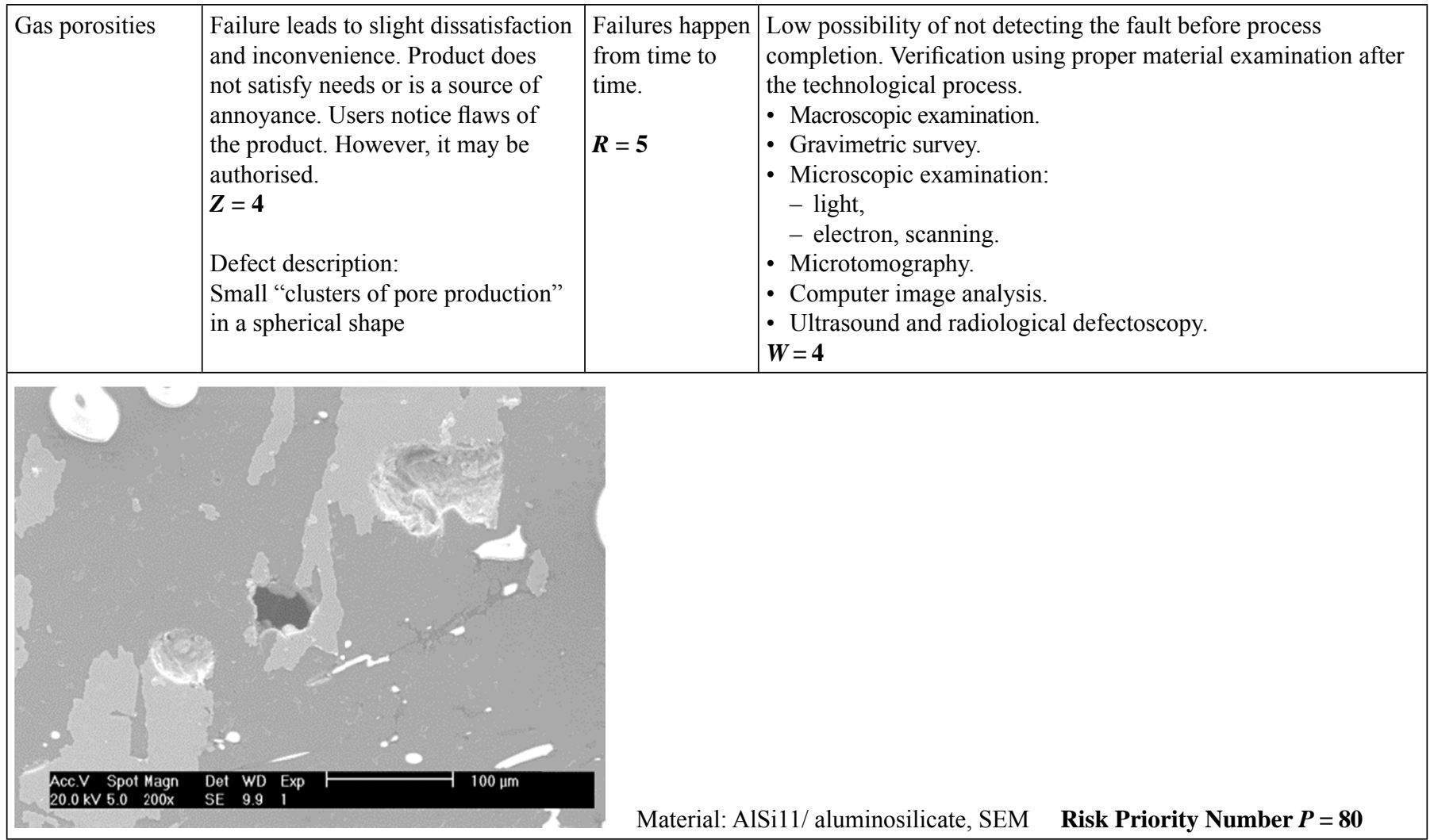

FMEA for the continuity defects subgroup (based on authors' work)

\begin{tabular}{|c|c|c|c|}
\hline Defect & $\begin{array}{l}\text { Defect significance for customer } \\
\text { (consequences, results) }(Z)\end{array}$ & Frequency $(R)$ & $\begin{array}{l}\text { Detectability }(W) \text { for conventional material castings }[1,13] \\
\text { and composite castings using proper research methods }\end{array}$ \\
\hline $\begin{array}{l}\text { Shrinkage } \\
\text { cavities }\end{array}$ & $\begin{array}{l}\text { The ramification of the failure is } \\
\text { grave, the casting is disqualified, } \\
\text { threatens the safety of users or } \\
\text { violates the law. } \\
\mathbf{Z}=\mathbf{1 0} \\
\text { Defect description: } \\
\text { Irregular continuity breaks in the } \\
\text { material, cone-shaped cavities with } \\
\text { a frequently developed and rough } \\
\text { surface }\end{array}$ & $\begin{array}{l}\text { Relatively } \\
\text { low level } \\
\text { of failures. } \\
\text { Controlled } \\
\text { process. } \\
R=2\end{array}$ & $\begin{array}{l}\text { It is highly unlikely that the failure will not be detected. } \\
\text { Verification using proper material examination after the } \\
\text { technological process. } \\
\text { - Macroscopic examination. } \\
\text { - Gravimetric survey. } \\
\text { - Microscopic examination: } \\
\text { - light, } \\
\text { - electron, scanning. } \\
\text { - Microtomography. } \\
\text { - Computer image analysis. } \\
\text { - Ultrasound and radiological defectoscopy. } \\
\mathbf{W}=\mathbf{1}\end{array}$ \\
\hline
\end{tabular}


TABLE 8. Continued

\begin{tabular}{|c|c|c|c|}
\hline $\begin{array}{l}\text { Shrinkage } \\
\text { Porosities }\end{array}$ & $\begin{array}{l}\text { The ramification of the failure is } \\
\text { grave, the casting is disqualified, } \\
\text { threatens the safety of users or } \\
\text { violates the law. } \\
\mathbf{Z}=\mathbf{1 0} \\
\text { Defect description: } \\
\text { Dense cluster of small porosities } \\
\text { with sharp contours and rough walls }\end{array}$ & $\begin{array}{l}\text { Relatively } \\
\text { low level } \\
\text { of failures. } \\
\text { Controlled } \\
\text { process. } \\
\boldsymbol{R}=\mathbf{2}\end{array}$ & $\begin{array}{l}\text { Low possibility of not detecting the fault before process } \\
\text { completion. The failure is evident, a few may remain undetected. } \\
\text { Verification using proper material examination after the } \\
\text { technological process. } \\
\text { - Macroscopic examination. } \\
\text { - Gravimetric survey. } \\
\text { - Microscopic examination: } \\
\text { - light, } \\
\text { - electron, scanning. } \\
\text { - Microtomography. } \\
\text { - Computer image analysis. } \\
\text { - Ultrasound and radiological defectoscopy. } \\
\text { W= } 1\end{array}$ \\
\hline 18 & & Material: AlS & Si11/ aluminosilicate, SEM Risk Priority Number $\boldsymbol{P}=\mathbf{2 0}$ \\
\hline $\begin{array}{l}\text { Fractures of } \\
\text { reinforcement } \\
\text { elements }\end{array}$ & $\begin{array}{l}\text { Failure leads to slight dissatisfaction } \\
\text { and inconvenience. Product does } \\
\text { not satisfy needs or is a source of } \\
\text { annoyance. Users notice flaws of } \\
\text { the product. However, it may be } \\
\text { authorised. } \\
Z=4 \\
\text { Defect description: } \\
\text { Break, fracture, discontinuity of } \\
\text { fibre }\end{array}$ & $\begin{array}{l}\text { Failures happen } \\
\text { from time to } \\
\text { time. } \\
\boldsymbol{R}=\mathbf{4}\end{array}$ & $\begin{array}{l}\text { Moderate likelihood of not detecting product fault before process } \\
\text { completion. Verification using proper material examination after } \\
\text { the technological process. } \\
\text { - Microscopic examination: } \\
\text { - light, } \\
\text { - electron, scanning. } \\
W=\mathbf{5}\end{array}$ \\
\hline & Fol wo $2 \frac{1}{3}$ & Material: AlS & Si11/C, SEM Risk Priority Number $\boldsymbol{P}=\mathbf{8 0}$ \\
\hline Matrix fracture & $\begin{array}{l}\text { The ramification of the failure is } \\
\text { grave, the casting is disqualified, } \\
\text { threatens the safety of users or } \\
\text { violates the law. } \\
\mathbf{Z}=\mathbf{9} \\
\text { Defect description: } \\
\text { Discontinuity in the matrix material }\end{array}$ & $\begin{array}{l}\text { Relatively } \\
\text { low level } \\
\text { of failures. } \\
\text { Controlled } \\
\text { process. } \\
\boldsymbol{R}=\mathbf{2}\end{array}$ & $\begin{array}{l}\text { Moderate likelihood of not detecting product fault before process } \\
\text { completion. Verification using proper material examination after } \\
\text { the technological process. } \\
\text { - Microscopic examination: } \\
\text { - light, } \\
\text { - electron, scanning. } \\
W=\mathbf{5}\end{array}$ \\
\hline
\end{tabular}




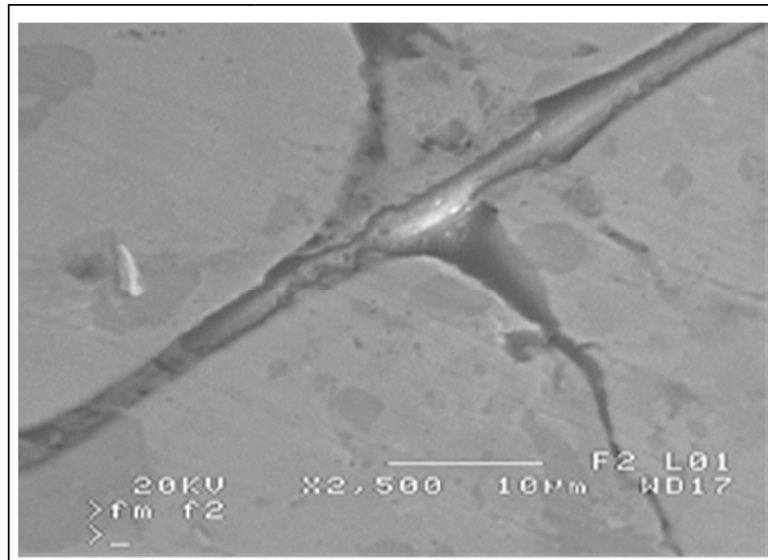

Material: AlSi11/ aluminosilicate, SEM Risk Priority Number $\boldsymbol{P}=\mathbf{9 0}$

\begin{tabular}{|l|l|l|l|}
$\begin{array}{l}\text { Fractures on } \\
\text { the matrix- } \\
\text { reinforcement } \\
\text { boundary }\end{array}$ & $\begin{array}{l}\text { The ramification of the failure is } \\
\text { grave, the casting is disqualified, } \\
\text { threatens the safety of users or } \\
\text { violates the law. } \\
\mathbf{Z = 9}\end{array}$ & $\begin{array}{l}\text { Failures happen } \\
\text { from time to } \\
\text { time. }\end{array}$ & $\begin{array}{l}\text { Moderate likelihood of not detecting product fault before process } \\
\text { completion. Verification using proper material examination after } \\
\text { the technological process. } \\
\begin{array}{l}\text { Microscopic examination: } \\
- \text { light, } \\
- \text { electron, scanning. }\end{array} \\
\mathbf{W = 5}\end{array}$ \\
$\begin{array}{l}\text { Defect description: } \\
\text { Lack of connection between the } \\
\text { matrix and reinforcement }\end{array}$ & & \\
\hline
\end{tabular}

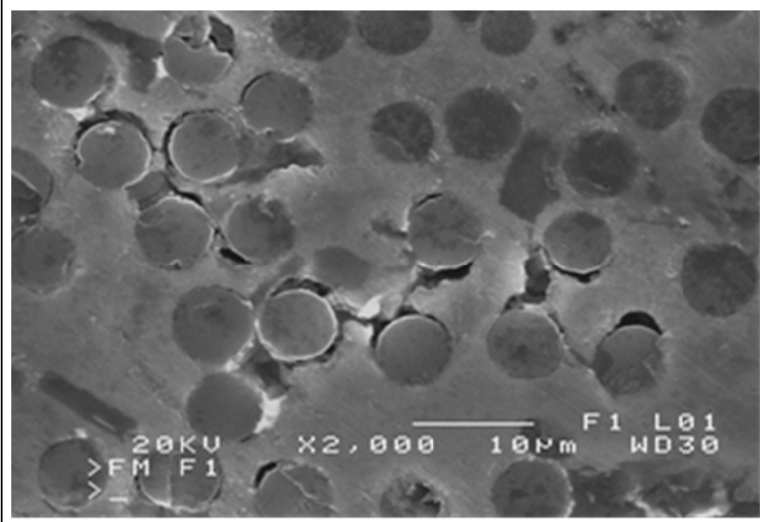

Material: AlSi11/ aluminosilicate, SEM Risk Priority Number $\boldsymbol{P}=\mathbf{1 8 0}$

\begin{tabular}{|c|c|c|c|}
\hline Hot crack & $\begin{array}{l}\text { The ramification of the failure is } \\
\text { grave, the casting is disqualified, } \\
\text { threatens the safety of users or } \\
\text { violates the law. } \\
\mathbf{Z}=\mathbf{9} \\
\text { Defect description: Thin, often } \\
\text { ramified crack cutting through the } \\
\text { product, visible on casting surface as } \\
\text { a zig-zag scratch }\end{array}$ & $\begin{array}{l}\text { Relatively } \\
\text { low level } \\
\text { of failures. } \\
\text { Controlled } \\
\text { process. } \\
\boldsymbol{R}=\mathbf{2}\end{array}$ & $\begin{array}{l}\text { Low possibility of not detecting the fault before process } \\
\text { completion. The failure is evident, a few may remain undetected. } \\
\text { Verification using proper material examination after the } \\
\text { technological process. } \\
\text { - Macroscopic examination. } \\
\text { - Microscopic examination: } \\
\text { - light, } \\
\text { - electron, scanning. } \\
\text { - Ultrasound and radiological defectoscopy. } \\
W=3\end{array}$ \\
\hline
\end{tabular}

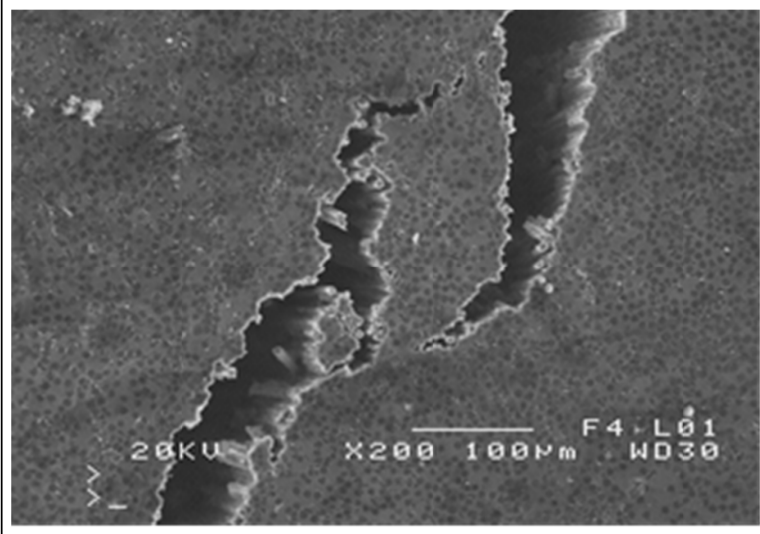


TABLE 8. Continued

\begin{tabular}{|l|l|l|l|}
\hline Cold crack & $\begin{array}{l}\text { The ramification of the failure is } \\
\text { grave, the casting is disqualified, } \\
\text { threatens the safety of users or } \\
\text { violates the law. } \\
\mathbf{Z = 9}\end{array}$ & $\begin{array}{l}\text { Relatively } \\
\text { low level } \\
\text { of failures. } \\
\text { Controlled } \\
\text { process. }\end{array}$ & $\begin{array}{l}\text { Low possibility of not detecting the fault before process } \\
\text { completion. The failure is evident, a few may remain undetected. } \\
\text { Verification using proper material examination after the } \\
\text { technological process. } \\
\text { - Macroscopic examination. } \\
\text { - Microscopic examination: } \\
\text { - light, } \\
- \text { electron, scanning. } \\
\text { Ultrasound and radiological defectoscopy. } \\
\text { Thin crack, visible on casting } \\
\text { surface as a regular scratch }\end{array}$ \\
\hline
\end{tabular}

\section{Conclusions}

An undeniable benefit of the FMEA method lies in the systematic approach to upgrade - oriented activities as it combines classic techniques and quality management tools [16, 17], demands approaching the problem from various perspectives $[18$, 19]. An elastic attitude is towards the specificity of a company, product/service may be noticed. According to FMEA assumptions, the higher the priority number $(P)$ value, the greater the risk assigned to a given failure. The conducted analysis proves that the most catastrophic failure (the highest value of the priority number $P=180$ ) affecting the quality of a composite casting is the failure: fractures on the matrix-reinforcement boundary, belonging to the continuity breaks subgroup. It is most significantly affected by the technological method (28.5\%) and, to the same extent, by the material used to create composite castings, then management, the human factor and technological stance (14.2\% each). It is fully comprehensible as the composite material may fulfil its function only if the matrix and reinforcement are fully "continuous." Cracks in the casting lead to product damage, consequently, to a failure of an entire mechanism in which a given element operates. The second place belongs to the defect $(P=108)$ : deformation of the reinforcing structure. Damaging, fracturing the reinforcing structure (though not frequent $R=4$ ) is a defect which deprives the composite of its basic function - strengthening the product. This may be caused by incorrect application of the technological process (e.g. too high pressure during saturation) or faulty materials. Third defect $(P=105)$ is: unfilled reinforcement spaces, also called insufficient saturation of the reinforcing structure with a liquid matrix metal. The factors of the greatest importance here include the technological method (26.6\%) and material (same percentage), then the human factor $(20 \%)$ as well as management and technological stance $(13.3 \%)$. It is impossible to use a composite casting which is not fully infiltrated as it cannot provide a full-value final product.

\section{Acknowledgments}

The publication funded by Ministry of Science and Higher Education of Poland from Grant 1/S/IESO/17 "Increasing operational effectiveness of complex technical systems by systematic development and implementation of innovations using novel materials and modifying the object's structure".

\section{REFERENCES}

[1] K. Gawdzińska, Materiałowo-technologiczne uwarunkowania jakości odlewów z metalowych materiałów kompozytowych, Wydawnictwo Archives of Foudry Engineering Katowice-Gliwice 2012.

[2] K. Manu Sree, L. Raag, T.P.D. Rajan et al., Liquid Metal Infiltration Processing of Metallic Composites: A Critical Review, Metallurgical And Materials Transactions B-Process Metallurgy And Materials Processing Science 47, 5, 2799-2819 (2016).

[3] K. Gawdzińska, L. Chybowski, A. Bejger, S. Krile, Determination of technological parameters of saturated composites based on sic by means of a model liquid, Metalurgija 55, 4, 659-662 (2016).

[4] J. Braszczyński, Teoria procesów odlewniczych, PWN, Warsaw 1989.

[5] M. Perzyk, S.Waszkiewicz, M. Kaczorowski, A. Jopkiewicz, Odlewnictwo. Warsaw WNT 2000. 
[6] ISO 9000:2015 Standard. Quality management systems - Fundamentals and vocabulary.

[7] ISO 9001:2015 Standard. Quality management systems - Requirements.

[8] A. Hamrol, W. Mantura, Zarządzanie jakością. Teoria i praktyka, third edition, updated, PWN, Warsaw 2006.

[9] Foundations of Effective FMEAs. Rev. 9.1. Reliasoft, Tucson 2012.

[10] J. Sobczak, Teoretyczne i praktyczne podstawy procesu prasowania w stanie ciekłym (squeeze casting) metali nieżelaznych, Prace Instytutu Odlewnictwa nr 41, Cracow 1993.

[11] A. Gatto, L. Iuliano, E. Atzeni et al., On the behaviour of reinforcements beneath the surface in turning of metal-matrix composites (MMCs), Journal of Composite Materials 50, 18, 2487-2494 (2016).

[12] A. Klasik, J. Sobczak, K. Pietrzak, Changes in properties of aluminum matrix composites reinforced with $\mathrm{SiC}$ particles after multiple remelting, Materials Research Innovations 15, Supplement 1, S249-S252 (2011).

[13] K. Gawdzińska, L. Chybowski, W. Przetakiewicz, Proper matrix-reinforcement bonding in cast metal matrix composites as a factor of their good quality, Archives of Civil and Mechanical Engineering 16 (3), 553-563 (2015)
[14] J. Sobczyk, L. Drenchev, Metalic Functionally Graded Materials: A Specific Class of Advanced Composites, Journal of Material Science and Technology 29, 4, 297-316 (2013).

[15] J. Sobczak, Metalowe materiały kompozytowe, Instytut Odlewnictwa 1996.

[16] D. Książek, M.J. Ligarski, Analysis of the functions and place of quality management systems in the context of an organization's development - a survey of the Polish Quality Award contest: Scientific Journals of the Maritime University of Szczecin, Zeszyty Naukowe Akademii Morskiej w Szczecinie 44, 116, 182-186 (2015).

[17] M. Molenda, Knowledge as a determinant in developing a quality management system: Scientific Journals of the Maritime University of Szczecin, Zeszyty Naukowe Akademii Morskiej w Szczecinie 39, 111, 116-121 (2014).

[18] L. Chybowski, K. Gawdzińska, W. Przetakiewicz, AHP based multi-criteria function analysis as a TRIZ tool for complex technical systems: Proceedings of the 13th MATRIZ TRIZfest 2017 International Conference, International TRIZ Association - MATRIZ, Knoxville 2017, 31-45.

[19] J.M. Ścierski, The use of quality management systems for limiting the risk of business processes: Scientific Journals of the Maritime University of Szczecin, Zeszyty Naukowe Akademii Morskiej w Szczecinie 32, 104, 108-114 (2012). 